\title{
The Landscapes of the Ancient Appia Project: Formation and Degeneration Processes in Landscapes Stratification of the Benevento Area.
}

\author{
Alessandro Terribile \\ University of Salerno, Dipartimento di Scienze del Patrimonio Culturale, Salerno, Italia \\ email: a.terribile85@gmail.com

\section{Cristiano Benedetto De Vita} \\ Università degli Studi di Salerno, Dipartimento di Scienze dei Beni Culturali, Salerno, Italia \\ email: cr.devita@gmail.com
}

\begin{abstract}
In this work we intend to illustrate methods and tools used for evaluating and defining some of the post-depositional processes of the archaeological record in the Eastern Beneventan landscapes. Our research aims especially to recognise the traces of the "longue durée" phenomena, highlighting what may be considered a result of the past still observable in the present. Which are the tools that allow us to identify landscapes marks, anthropogenic and environmental processes responsible of the survival or, conversely, of the obliteration of the ancient forms? A first approach attempts to create a dialogic relationship with the historical cartographic documents (such as ancient cadastres, notarial instruments, boundary disputes) and sheds light on the dynamics of the perceptible transformations of landscapes, bringing back an overall view of their contextual distinctive traits. This ensures the identification of "ecofacts" and "artefacts" that contributes to the structuration of the landscapes that have occurred over time as stratified units. A second procedure involves the reading of the historical information combined with the environmental one, through an archaeomorphological approach. The study has provided an overlap among the ancient and modern rural fabrics (for example roads, canals, talwegs, agrarian boundaries) and the geomorphological dynamics, with the aim of discerning the forms of degradation and to define, when possible, a relative chronology. Such an approach evaluates the
\end{abstract}

distribution of surface artefacts and their spatial and temporal characteristics, enabling recording of the higher or lower level of degradation in the archaeological record, emphasising those landscapes units considered of high information potential.

Keywords: Benevento, Ancient Appia Landscapes, Historical Cartography, Archaeomorphology, Post-Depositional Processes.

\section{Introduction}

The study presented in this paper focuses on the dialogical relationship between the cartographic documentation, which represents the interpretation of landscape and human activities that transform it, and the analysis of the morphogenetic phenomena that shape and modify a context. This work is part of the Ancient Appia Landscapes project, carried out beginning in 2010 by the University of Salerno in collaboration with the Soprintendenza Archeologica of Salerno, Avellino, Benevento e Caserta (Tomay, Santoriello \& Rossi, 2012). The research aims to study the path of the Via Appia in the ancient Beneventum area and to identify the environmental phenomena, socioeconomic and productive activities that influenced the settlement dynamics before, during and after the construction of the consular road.

The research covers a broad area east of the city of Benevento, defined by Irpinian Appennines 
to the south and the Calore River to the east and to the north. In this sector the Appian path is outlined by the ancient itineraria, according to which it is possible to identify two stationes just outside the city: Nucriola or Nuceriola, located at the fourth mile, and ad Calorem, which probably was near Ponte Rotto, an important bridge of the Imperial Age placed at the tenth mile from Benevento and used to cross the Calore in the direction of Aeclanum (Meomartini, 1896). The little archaeological data in this area consist mainly of bibliographic information and archival materials (fig. 1).

However, there are several hypotheses that attempt to reconstruct the Appian path, some of them developed by local scholars between the late nineteenth and the early twentieth centuries. A. Meomartini supposed two different paths: the first passing through Contrada Cancelleria, recognised as the statio of Nuceriola (Meomartini, 1896) and the second one, based on archaeological finds, with the aforementioned statio located further south, in the area of Contrada Piano Cappella (Meomartini, 1907).

In the eighties of the last century, L. Quilici suggested a path in correspondence of San Cumano, where some archaeological remains were found (Quilici, 1989). The area was also investigated by the team of Besançon, which identified two hypothetical cadastres, respectively of the Triumviral period (Beneventum I, 20x20 actus, N 42 ${ }^{\circ} \mathrm{E}$ ) and of the Augustan era (Beneventum II, $16 \times 25$ actus, N $2^{\circ}$ W) (Chouquer et al, 1987). Recent reconsiderations about Beneventan cadastres did lean towards a new dating: the years of the colonial foundation (after 268 a.C.) for the Beneventum II, the Triumviral-Augustan Age for the Beneventum I. The Ancient Appia Landscapes team has also identified some orientations in the Cubante plain, considered as possible traces of a third cadaster, indicated as Beneventum III (Santoriello, 2014).

The research on the Appia landscapes aims at a "global" approach, based on a profitable exchange of knowledge between different branches.

The collection of archaeological data previously published, or conserved in the state archives, has been the first step of the research. Several interventions related to preventive archaeology, managed by the University of Salerno, along with a site survey, allowed us to draft a first GIS-based archaeological map. This was the basis for geomorphological and topographical surveys, intensive and extensive surface artefact collections and geophysical prospections. The survey activities investigated all aspects that contribute to reconstruct the historical dimension of the context and to identify the stable "landscape units", connected to the actual layout or surviving as fossils.

This paper highlights some of the methods used in the research, such as the documentary value of historical maps and the study that correlates geomorphological phenomena with the results of surface survey and archaeomorphological data.

\section{Methodology}

\section{Historical Maps between Continuity and Changes}

The study of Benevento's historical maps was started from the analysis of the socioeconomic and political context that produced this kind of documentation over the course of time. The Beneventum area, seen from an historical point of view, appears to be complex because of its geopolitical condition of borderland. In fact, Benevento was a Pontifical exclave from 1055 to 1861 but the city's territories were mainly fragmented in extensive estates controlled by powerful ecclesiastical entities and important noble families. These properties were described as "fiefs" in the official documentation until the nineteenth century.

Such knowledge has allowed us to better organise the research. The first step involved the retrieval of cartographic data, with particular attention to official authorities that seemed potential holders of historical cartography.

The geopolitical and juridical complexity is demonstrated by the presence of huge properties fragmented and concentrated in the hands of many different entities. Since 1135, the Ab- 


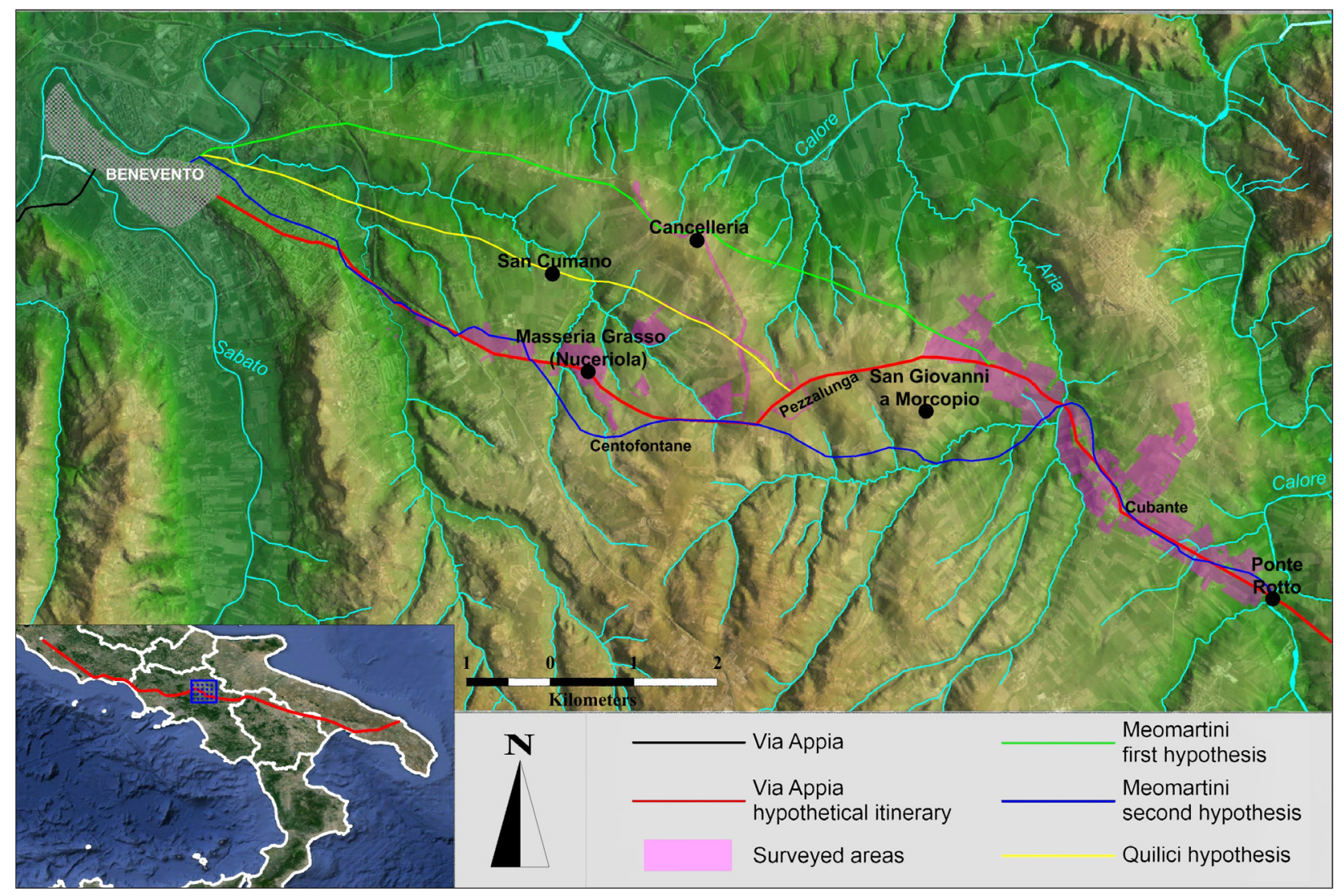

Fig 1. Location of the study area and the Appian route hypotheses.

bey of Montevergine, situated in the territory of Avellino, owned a large number of lands - in the Cubante plain and in San Giovanni in Morcopio managed by small local churches. Similarly, the Abbey of Santa Sofia, located in the city of Benevento, controlled extended portions of territory, including San Cumano and Contrada Pacevecchia. The noble families of Montefusco and Dell'Aquila possessed less ample estates and often came into conflict with the ecclesiastical institutions regarding borders.

Overall, eight archives have been investigated in a very focused way, more than 50 catalogues were consulted, yielding a total of 410 maps, which are both chronologically and typologically heterogeneous with an extension of time from the second half of 1600 to the beginning of the twentieth century. The different criteria of representation and measurement have been processed with the creation of an Information System of the collected data, able to manage and interrogate each acquired unit. This operation was essential because it produced paradigms of conjunction or discordance between documents generated by various needs: for example, a notary deed has different utility in comparison with a cadastral map.

Collecting and processing data, some documents have been discarded for size and realisation technique because they did not provide useful elements for the purposes of this study. The selected documents were georeferenced, identifying those that could be called "matrix elements" and could be recognised in the actual shapes of the landscape (Tosco, 2009). Crossroads, masserie and churches have been used to snap the Ground Control Points (GCP). The cartographic filtering follows two rules: firstly, maps were overlapped with a reverse chronological order, starting from the most recent to the oldest. The second principle is based on the difference of scale factors that requires 
georeferencing maps proceeding from the general to the particular, namely from the document with the highest denominator until the one with the minimum scale. Specifically, inside a table of the Catasto Gregoriano, it is possible to insert plans extracted by notary deed within the same area.

\section{Formation and Degeneration Processes Resulting from Geomorphological Analy- sis}

A different research approach was intended to identify some of the environmental changes that have affected and still affect the present landscape, through the selection of geomorphological units that constitute its structure. This mapping separates environmental changes from human processes, allowing the creation of a hierarchy of territorial shapes and allowing us to distinguish the stable areas from those of erosion and deposition.

Such support has been overlaid on a $5 \mathrm{~m}$ resolution DEM, together with the archaeological finds collected during the survey: in this way, the direct comparison between geomorphological phenomena and density of the archaeological record, defines the effect of post-depositional processes on the spatial entity of the archaeological data. This allows more immediate identification of insite, off-site and sub-in-site materials - the latter definition can be related to those cases where the artefacts, despite having suffered minor phenomena of dislocation, can be referred again to their original context through the assessment of a 'direct genetic link' (Leonardi, 1992).

Another important aspect is the chronological period to which an artefact assemblage is dated. This information allows us to bring out the cultural, social and technological aspects that are responsible for the development of the archaeological deposits. Just as an example, it is logical to think that during the Imperial Age and Late Antiquity, the agricultural practice of manuring influenced the spread of fragments over wide areas, producing a dispersion that cannot be linked to a punctual activity. On the other hand, prehistoric and protohistoric artefacts are spatially much more concentrated. Therefore, for these periods, it is difficult to detect off-sites activities on a large scale and fragments identified in wide dispersions are often connected to human or environmental post-depositional processes. The analysis also takes into account the condition and the degree of pottery fragmentation. Very worn and fragmented sherds may indicate the significant impact of post-depositional processes (De Haas, 2012).

The archaeomorphological analysis enables us to evaluate if the obliteration dynamics of the archaeological record produces the same results on the iso-oriented forms of the landscape. The application of a relative chronology between iso-oriented forms and geomorphological dynamics would allow differentiating the residual elements of the agricultural landscapes from recent assets. The occurrence of a high level of conservation defines the identification of landscape units in which the historical value is still preserved.

It has been decided to overlay the geomorphological units and the three hypotheses of centuriation, namely Beneventum I, Beneventum II, and Beneventum III. We can see from this overlay the information potential of the landscape units. This outcome does not define a hierarchy between landscapes, since the better preserved may not have more value: in fact, the degradation of a space and the succession of different shapes which tend to nullify the historical value, are itself useful information for a regressive interpretation of the landscape. Therefore, it is necessary to clarify the difference between "information potential" and "conservative potential" (Serlorenzi et al, 2012) which do not always coincide: the information potential of a territory is strictly related to the phenomena that have changed it. The degradation of the terraces, the formation of marshes, the slope landslide inform us of past landscapes features; the involvement of the archaeological evidence in these dynamics allow us to assess its evolution in relation to human activities. In this sense, the post-depositional processes of the archaeological record become the indicator of the 


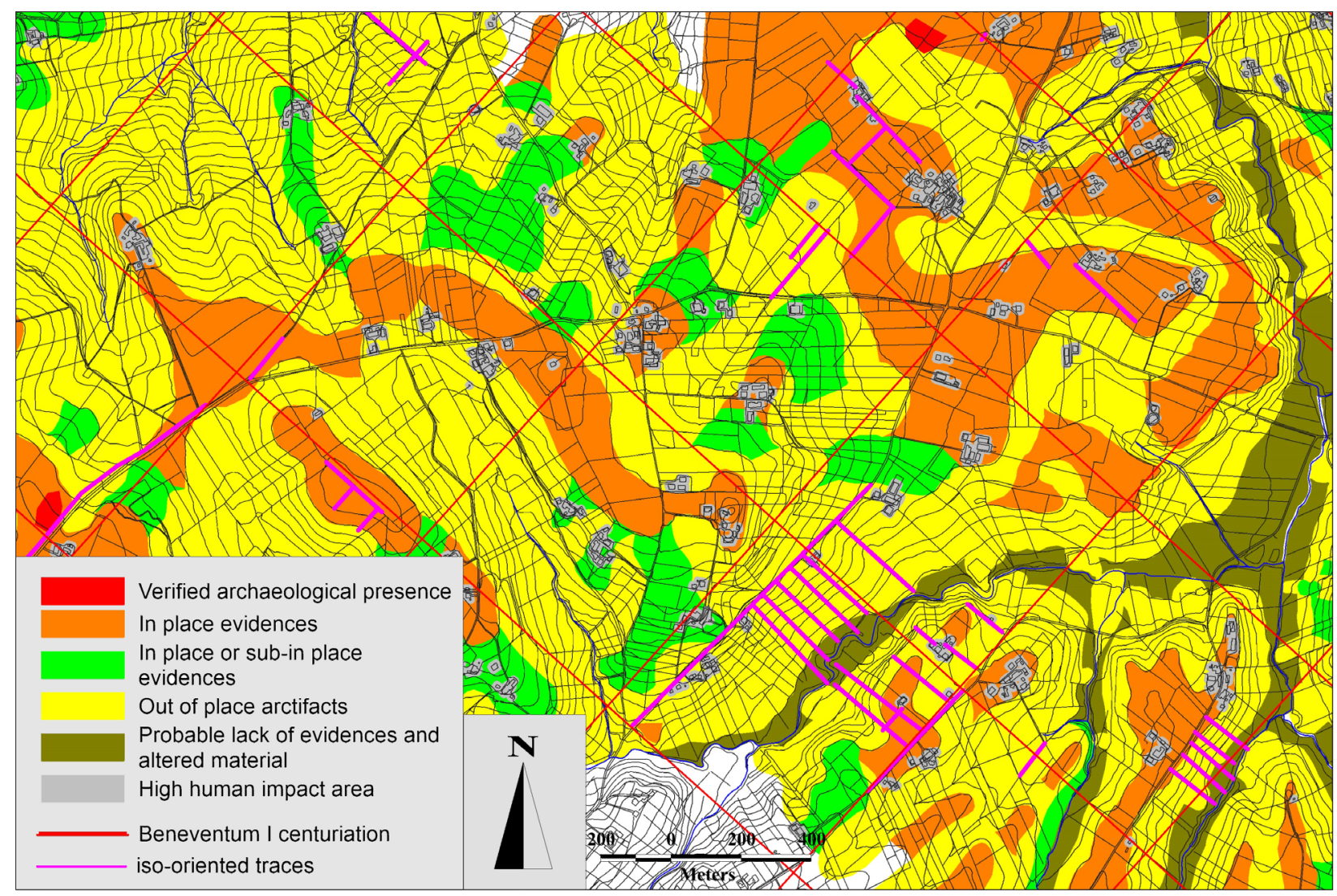

Fig 2. Località Pezzalunga - San Giovanni a Morcopio: A map of potential information of landscape units with the Beneventum I centuriation grid.

conservation of the past territorial organisation (fig. 2).

Geomorphological and cartographic data has been included into the Ancient Appia Landscapes GIS, in order to compare them in the process of analysis.

\section{Results}

The research is still ongoing, but we have enough information to highlight a pre- and proto-historic structured system that demonstrates continuity in settlement choices despite large chronological caesurae. The sectors with the highest frequentation have been identified along the limits of the terraces close to waterways. Most of the occupied areas have a frequentation distributed over time, attributable to Early Neolithic, Recent Eneolithic and the Middle Bronze Age. In this case, it would be worth speaking of "areas of frequent occupation".

In historical times, the population of the Benevento territory is perceivable at least since the fourth century BC, until Late Antiquity according to a process of occupation which gradually involves lands ever more distant from the colony. In this interpretation, the recognizable longue durée phenomena seem to characterise a reorganisation of rural areas interconnected with the current social and political needs. This gives a new interpretation on centurial systems which structured themselves during wider chronological ranges. It is also possible to hypothesise a third centuriation of Middle-Imperial Age, near Ponte Rotto (20x20 actus, $\mathrm{N}-29^{\circ} \mathrm{E}$ ). The overview provides recognition of only some sections of the ancient road network and its fixed-points are the stationes of Nuceriola and Calorem. According to the definitive identification of 
Nuceriola, it is possible to assume an Appian path that started from the south-east of Beneventum, where Rocca dei Rettori is now located. There are currently no reliable data on the possibility of Appia's rerouting during the Trajan-Hadrian's period, but the existence of occupied areas only as of the Middle Imperial Age could justify such hypothesis. At the moment it is significant that the landscape of historical times appears affected by an articulated and differentiated road network that partly survives until today. On the basis of the above, the analysis has focused on the three significant sectors covered by the project: the area of Masseria Grasso-Piano Cappella, the terraced areas of San Giovanni in Morcopio and the Plain of Cubante.

Meomartini's investigations conducted in the sector of Masseria Grasso-Piano Cappella at the beginning of the twentieth century have found numerous validations during the field survey. It has been demonstrated a significant attendance at least from the fourth-third centuries BC, with a chronological gap to the Late Republican era, when it seems to develop again and proceed until at least Late Antiquity. From a geomorphological point of view, the site alternates stable areas, represented by natural terraces, to slopes with heavy erosion, which are, in many cases, the creep phenomena of the surface layer along the edges that can affect even significant shims in the form of landslides. The archaeological deposits placed on the terraced areas have therefore suffered minor dislocations, almost exclusively due to recent ploughings. The geomorphological phenomena influenced the preservation of some tracks iso-oriented pertinent to Beneventum I of Augustan Age.

These marks were added to the identification, in 1903, of a paved road in the same mesh centurial orientation, which was mapped and interpreted by Meomartini as a section of the Appia. Overlaying the relief carried out by the scholar and hypothetically extending it, it is possible to intercept a number of roads and field limits still in use, slightly divergent or translated. Such a path would encounter depositional and erosional areas that have probably influenced the guidelines change, as can be seen from the cross-section (fig. 3).
Continuing Northeast, there are saddles that connect this sector with the Pezzalunga and San Giovanni area in the direction of Ponte Rotto. The conservation of these traces shows the stable areas conservatism and the continuity of use of this sector that still has crop suitability and considerable importance for mobility, confirming what was already said by Meomartini. This phenomenology concerns the Early-Medieval period and is reflected both in literature and historical maps. In this area the toponyms are substantially unchanged. The statio "Nuceriola" on the Tabula Peutingeriana appears with degraded form "Luceriola" in the Chronicon Sanctae Sofiae at the time of Arechi II (Martin, 2000) and it is confirmed by the cartography of Montevergine Abbey, in the early part of the eighteenth century, with the name of "Recerola". Moreover, the area of Masseria Grasso assumes particular importance since at least the eighth century AD, when the church of Santa Maria a Voto was founded. It connotes the medieval landscape, surviving until the first half of the nineteenth century, when it is registered in the Catasto Gregoriano (1825). This cult assumes a symbolic value linked to the conversion of the Longobards attributed to Saint Barbato, bishop of Benevento, from which derives the suffix, votum, transmitted by the sources (Martin, 1974). The episode, beyond the symbolic connotations, would further demonstrate the nodal role that the area of Masseria Grasso Nuceriola held in the organisation and the control of this territory.

The area of San Giovanni a Morcopio shows very different features. It is composed by two large erosional terraces on which the Besançon team has identified some relevant traces that can be reported to both the centurial grids. On one of the terraces, located on the top stands the church of San Giovanni a Morcopio, property of the Abbey of Montevergine since at least the year 1135. To the east, at the confluence of two secondary streams with the Aria watercourse, slopes with steep and eroded surfaces surround a floodplain.

The surveys have identified poor traces of frequentation, mostly attributable to the Early Neolithic and to the Middle Bronze Age, and at least a 


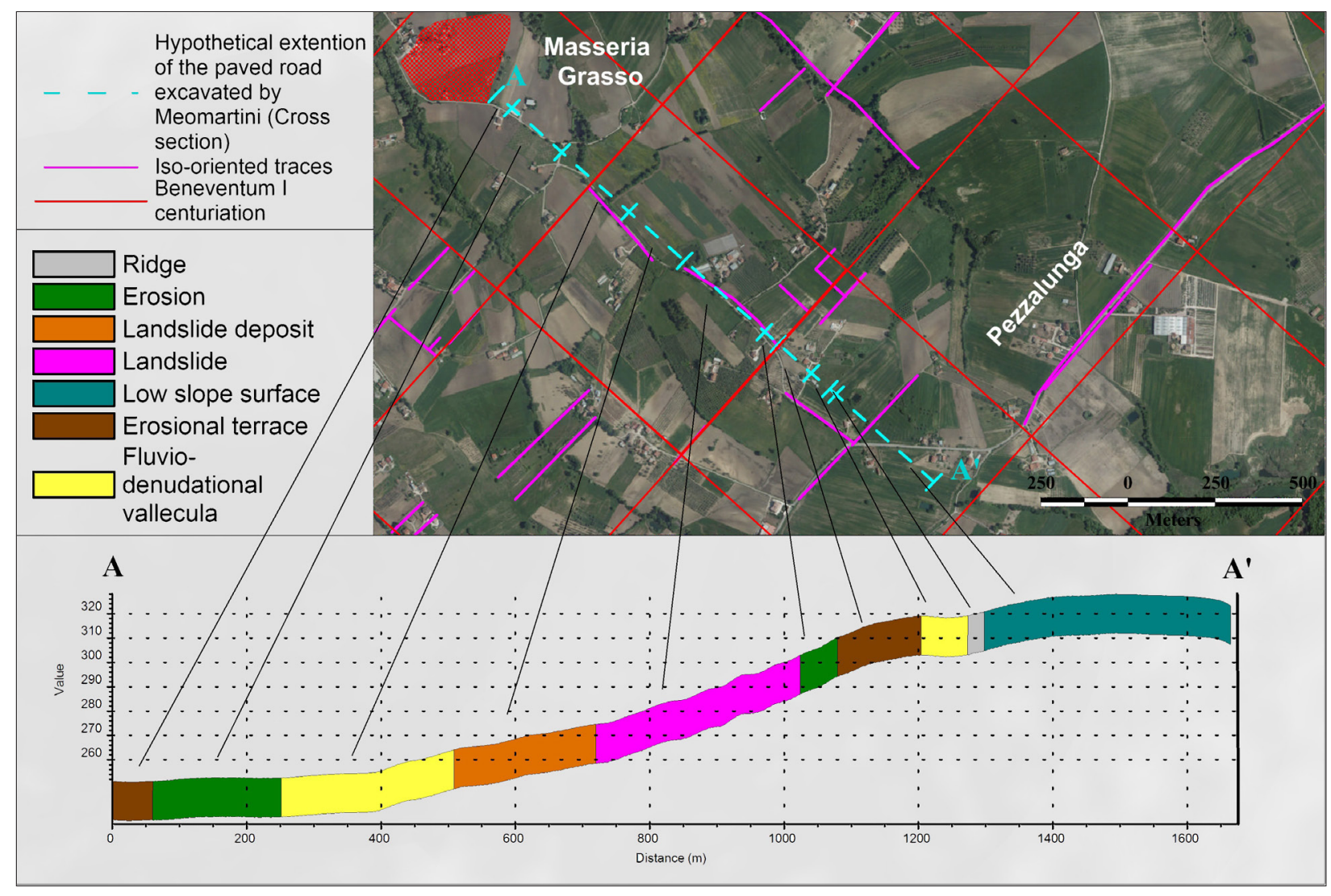

Fig 3. Masseria Grasso. Cross section of the hypothetical extension of a paved road excavated by Meomartini.

Late Antiquity settlement. However, the historical maps reveal several elements of continuity in the exploitation of the terraces, whose streets and field boundaries seem to maintain the orientation of the centurial grids.

An exception is the area located just below the east side of the San Giovanni terrace, where the Montevergine maps, dating back to 1714 , reveal the presence of a road apparently oriented as the Beneventum I. This path has undergone a transition in the direction of the Aria stream bank no longer visible in the aerial photos of the 1950s. The result of this transition is mainly due to the presence of several landslides and fluvial-denudational valleculas along the slopes, whose result is well highlighted by deposition layers and alluvial fans. In the first half of the twentieth century work was required to stabilise the area which led to the construction of several terracing works, nowadays half-buried but still legible in the old aerial photos. Some toponyms referring to the alluvial plain seem to recall waterlogging phenomena that would have affected areas pertaining to the rivers confluence. The terms such as "Silva Mala" (Wicked Woods) attested in the thirteenth century and "Paluda Nigra" (Black Marsh) of the second half of 1600 testify to the presence of inhospitable environments that influenced the human dynamics of the area, which, however, appear to be an obligatory way in the direction of Ponte Rotto and Irpinia. Not surprisingly, the name of the ford on the Aria stream at the end of 1600 is "Varco di Puglia" or Passage for Puglia.

Beyond the toponomastic data, some deposition layers show cyclical events of flooding and of being waterlogged. Large swathes of pumice, mixed up by plowing and related to the Avellino eruption (3800 ka BP), have been identified on the slopes of San Giovanni terrace, as well as along on those arranged around the plain, at a constant altitude of 220-225 m above sea level. Volcanoclastic mate- 


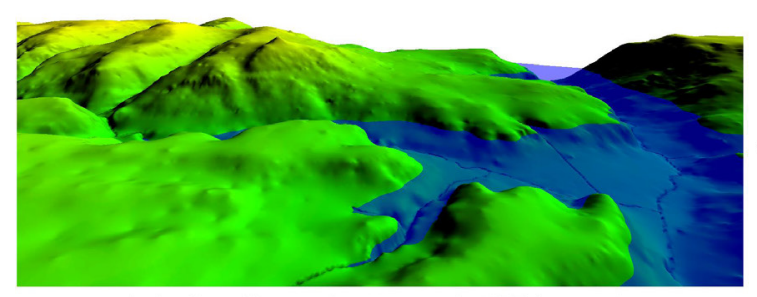

Lake Basin in San Giovanni a Morcopio (3800 ka BP).

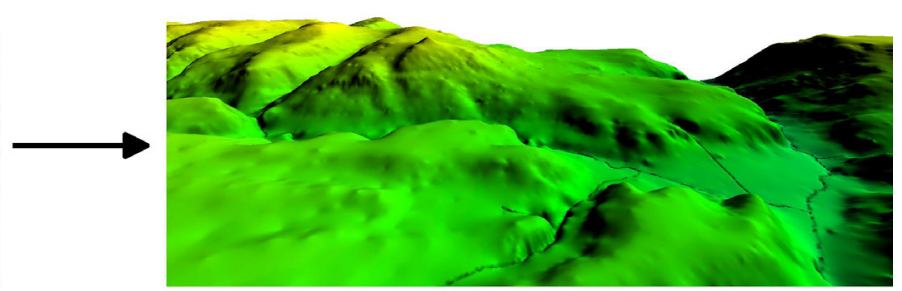

San Giovanni a Morcopio Area nowadays.

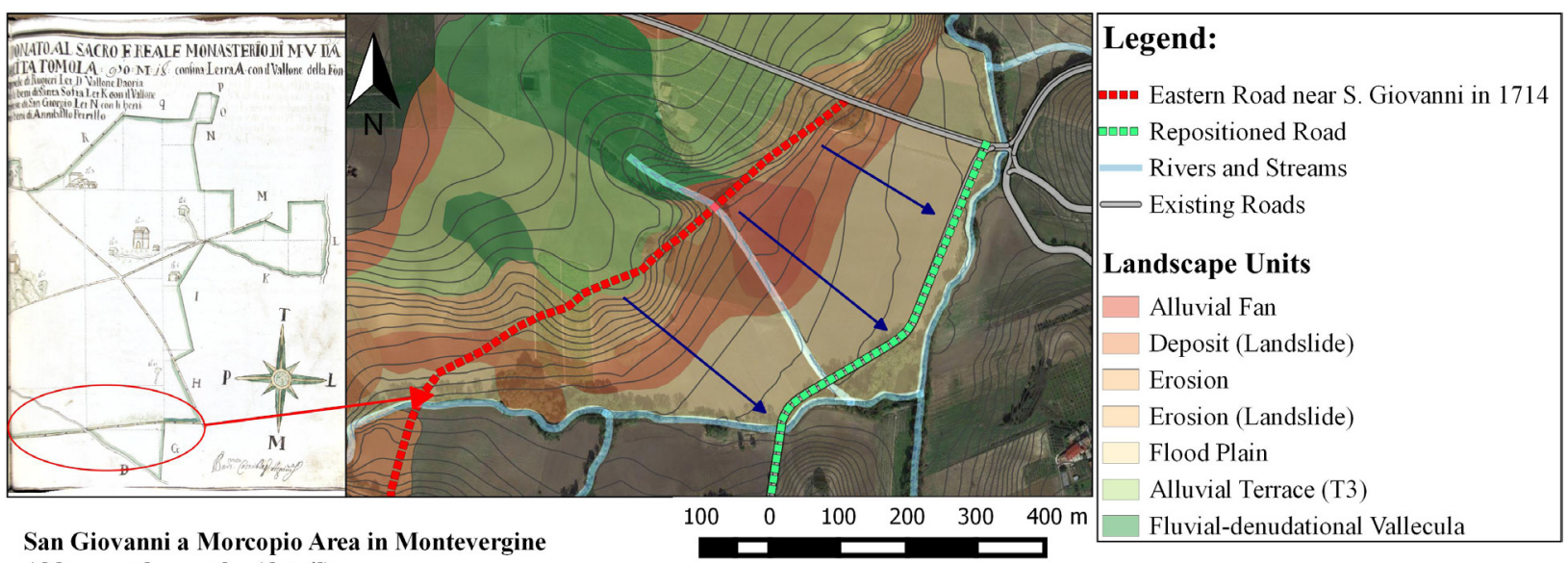
Abbey carthography (detail).

Fig 4. San Giovanni a Morcopio. DTM with reconstruction of the Lake Basin (top left) and the same area today (top right). Ancient Map of Montevergine Abbey from Platea II - 1714 (bottom left) and detail of a road that no longer exists (bottom right).

rials could have been deposited along the shores of a considerable stretch of water, placed in the actual plain. This lake, probably already existing at the end of the Early Bronze Age, would have been formed after a massive landslide further downstream, which would have obstructed the basin therefore making drainage impossible (fig. 4). In consideration of the above, this sector, despite the high instability of environmental phenomena, has always been the subject of constant consolidation and recovery actions, as necessary transit point in the direction of the Calore River and Irpinia.

Although investigations are still in progress, the Cubante plain appears as an area of particular importance regarding agricultural use, as well certified by the earliest documentary sources, dating from the second half of the eighth century. The surveys have shown the presence of a settlements network homogeneous for chronology and functions, with evidence from the first century BC until at least the fifth century AD. These settlements seemed to have been developed in conjunction with the construction of Ponte Rotto, probably occurring along with the restoration of the Via Appia commissioned by Hadrian in AD 123, as proved by a decontextualised milestone originally posed at the tenth mile from Beneventum - perhaps on the site of the statio ad Calorem signaled by the Tabula Peutingeriana $(A E, 1930,0122)$.

Unfortunately, the historical maps of $\mathrm{Cu}$ bante plain turned out to be incomplete. Until the confiscation of the ecclesiastical property, which occurred in 1867, this territory mostly belonged to the Abbey of Santa Sofia of Benevento. A cartographic document of 1669 shows in the western portion of the plain the clear survival of several roads oriented according to the Beneventum III 


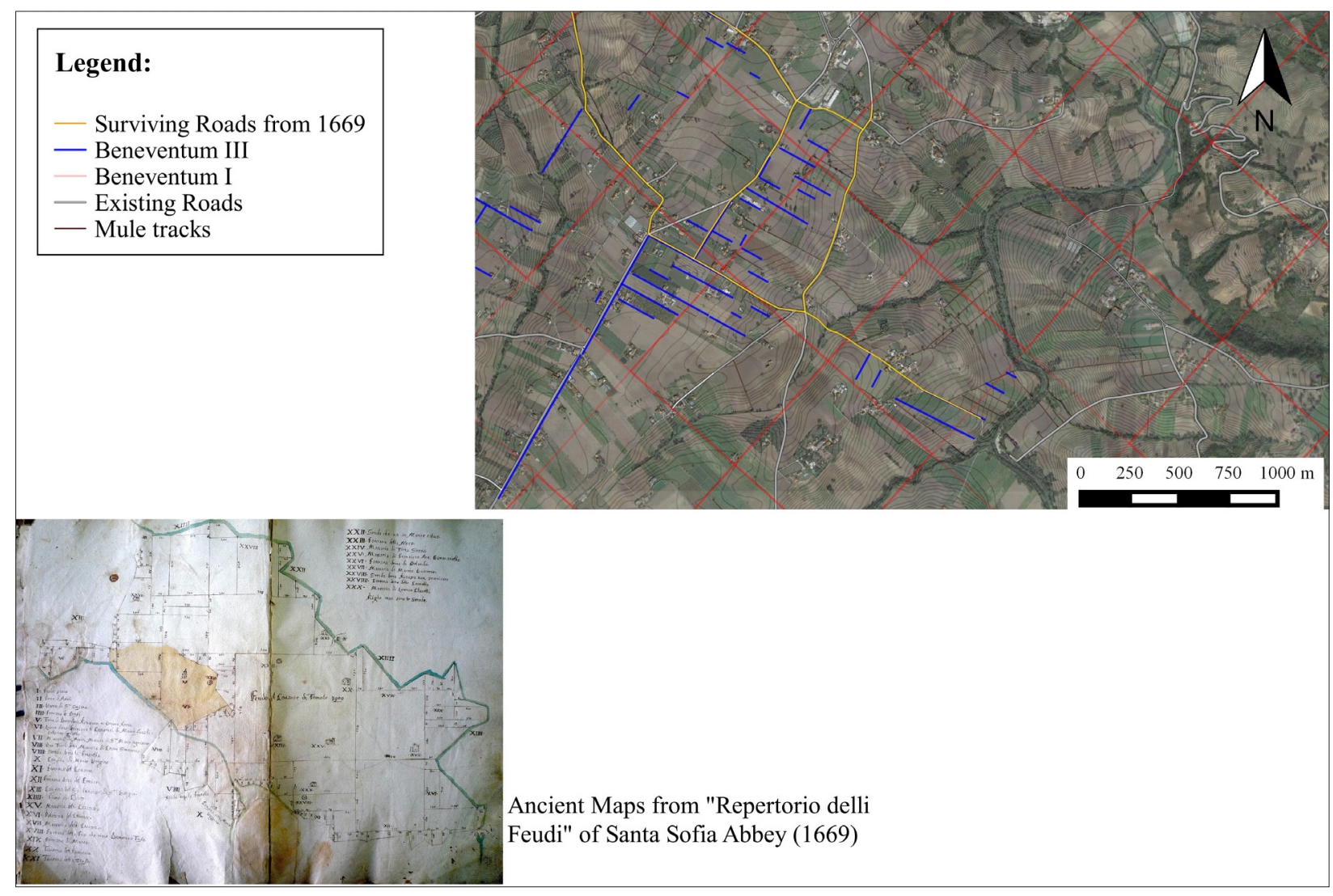

Fig 5. Cubante. Roads as seen in the Repertorio delli Feudi (1669) of Santa Sofia Abbey overlapped with existing roads and two Centurial Systems (Beneventum I - Beneventum III).

grid. An intensive exploitation of the land emerges both from the documentation and from the maps of this time, destined for arable crops and pasturelands. This aspect is important to explain a certain degree of conservation, assent only in the areas of constant reclamation near the Calore River. A further confirmation comes from the geomorphological data: the sector is characterised by wide terraces declining towards the Calore valley and the only forms of erosion consist of some fluvio-denudational valleculas that affect the edges of low sloping surfaces. Archaeomorphological data concern some traces with the same orientation of Beneventum / but they are located only in the western sector of the plain. As noted by A. Santoriello, the imperial cadastre of $20 \times 20$ actus $\mathrm{N} 29^{\circ} \mathrm{E}$ can be seen throughout the area. The cadastre seems to source from the orientation of the Ponte Rotto ramp and to exploit the natural conformation of the terraces. Now it is difficult to assess whether the Beneventum / cadastre has been completely supplanted by Beneventum I/I in this area, or whether it has partially coexisted with the one of the Imperial Age (fig. 5).

\section{Conclusion}

The combined use of geomorphological analysis and historical cartography allows us to reconstruct an evolutionary framework of formation and degeneration processes occurring in time in a specific territory. In the presence of environmental phenomena detected by a careful observation of the landscape units, man has also left a tangible mark resulting in changing forms of settlements aimed at the use of land and of its resources.

By consulting the cartographic documents produced since the seventeenth century, circumstan- 
tial factors arise which, even if seemingly marginal, provide a clear perception of the changes incurred within a given area. The variation of crops and limits of a field, besides transmitting information of economic nature, often explain the need to adapt the cartographic product to the changed conditions of an area, through different editions. The reason behind the creation of a cartographic document is identifiable in social, economic and environmental facts that interact directly on the shape of the landscapes, in a sort of transitive property between the instrument and the context from which it was generated.

The overlap of multiple supports, where the georeferencing operation has made it possible, has shown that the field boundaries have not suffered excessive variations, except in cases where they were located in unstable points of the landscapes - as peri-fluvial belts, heavy erosion slopes, etc. This fact is linked to two main reasons. The first concerns the continuity of ownership claimed on large properties by ecclesiastical entities which allowed a sort of immutability. The second is linked to a juridical cause as the ancient system of emphyteusis ensured long periods of administration in the hands of a single family unit - every stipulation provided a twenty-nine year period. The heirs could also renew the lease and this ensured a kind of conservatism of the individual properties.

Another result concerns the infrastructure, especially major roads: they were subjected to translation or degradation under strong influential socio-economic phenomena, or, alternatively, to environmental transformations that affected the conformation of the agrarian cadastre.

The overlap of geomorphological and archaeomorphological data with the large amount of information derived from the cartographic documentation has also allowed recognition of cyclical elements that influenced the vocation of landscapes, their shape and human activities even without substantial surface evidence. Such approach, developed and applied in a systematic way, would lead to "regressive" reconstruction of the landscapes without excluding from the research ethos elements that only apparently doesn't have potential information.

\section{References}

Carosella F, Cocca B, Platea n. 2, 1710, Unpublished Manuscript, Biblioteca Statale di Montevergine, Mercogliano.

Chouquer G, Clavel-Leveque M, Favory F \& Vallat J-P, 1987: Structures agraires en Italie centro-meridionale: cadastres et paysages ruraux, Ecole Francaise de Rome, Rome.

De Haas T, 2012: Beyond dots on the map: intensive survey data and the interpretation of small sites and off-site distributions, in Attema P \& Schörner G (ed.), Comparative issues in the archaeology of the Roman rural landscape, site classification between survey, excavation and historical categories, Journal of Roman Archaeology, supplementary series 88, 55-79.

Leonardi G, 1992: Assunzione e analisi dei dati territoriali in funzione della valutazione della diacronia e delle modalità del popolamento, in Bernardi M (ed.), Archeologia del Paesaggio, IV ciclo di lezioni sulla ricerca applicata in archeologia, Certosa di Pontignano, January 14-26 1991: 25-66. All'Insegna del Giglio, Florence.

Martin JM, 1974: À propos de la "Vita" de "Barbatus" évêque de Bénévent, in Mélanges de l'Ecole française de Rome. Moyen-Age, Temps modernes, vol 86.1: 137-164. École française de Rome - De Boccard, Rome.

Martin JM (ed.) 2000: Chronicon Sanctae Sophiae: cod. Vat. Lat. 4939, Istituto Palazzo Borromini, Rome.

Meomartini A, 1896: Del cammino della Via Appia da Benevento al Ponte Appiano o Ponte Rotto sul Calore, L. De Martini, Benevento.

Meomartini A, 1907: Del cammino della via Appia verso Brindisi nel territorio di Benevento, del sito di Nuceriola e degli scongiuri di San Barbato, L. De Martini, Benevento.

Quilici L, 1989: Via Appia: dalla pianura Pontina a Brindisi, Palombi, Rome.

Repertorio delli Feudi, 1669, Unpublished Manuscript, Biblioteca del Museo del Sannio, Benevento.

Santoriello A, 2014: Paesaggi agrari della colonia di 
Beneventum, in Lambert C \& Pastore F (ed.), Miti e popoli del Mediterraneo Antico. Scritti in onore di Gabriella D'Henry: 257-65. Arci Postiglione, Salerno. Serlorenzi M, F Lamonaca, S Picciola \& C Cordone 2012: Il Sistema Informativo Territoriale Archeologico di Roma: SITAR, Archeologia e Calcolatori, 23, 55-75.

Tomay L, A Santoriello \& A Rossi 2012: La via Appia tra tutela e ricerca: recenti indagini di scavo e studi sul territorio beneventano, in Ceraudo G (ed.), Lungo l'Appia e la Traiana. Le fotografie di Robert Gardner in viaggio con Thomas Ashby nel territorio di Beneventum agli inizi del Novecento, British School at Rome Archive 10: 19-29. Delta 3, Grottaminarda.

Tosco C, 2009: Il Paesaggio Storico. Le fonti e i metodi di ricerca tra medioevo ed età moderna, Editore Laterza, Bari. 
